\title{
The Latex Cast of Cistern and \\ Duct System of Dairy Cow's Udder
}

\section{Yozo Shinde and Masakazu SakuraI}

Department of Animal Science, Obihiro University of Agriculture and Veterinary Medicine, Obihiro-shi 080

(Received November 14, 1984)

\begin{abstract}
A method to produce latex cast model of cow's cistern and duct system was developed in order to clarify the internal structure of the udder and to measure the holding capacity of the milk storing system. Udders of ten lactating, ten dry Holstein cows and three growing heifers were collected and the latex casts of their cisterns and duct systems were prepared. The capacities of the milk storing systems, the numbers and location of the ducts, and the size and shape of cisterns were measured on the latex casts. 1) The technique used in the present study made it possible to fill the whole milk storing systems down to lobule level, using a latex solution with a suitable viscosity of the material. The cast can be used to estimate the size and shape of milk storing system in cows and growing heifers. 2) The average milk storing capacity of the left half for lactating cow's udder was $4.71 \pm 0.921$ (Mean \pm SD). The fore quarters was $39.05 \%$ of the whole udder. The average milk storing capacity of left half for dry cow's udder was $2.85 \pm 0.96 l$ while that of the fore quarters was $37.81 \%$ of whole udder. There was significant difference in milk storing capacity of the left half between dry and lactating cows $(P<0.05)$. 3) Gland cisterns were classified into five types: divergent, ball, egg, columnar and part-divergent types, the percentages of which were $45,12.5,10$, 15 , and $17.5 \%$, respectively. The size of cistern greatly varied in different cows and in different quarters of the same udder. 4) The number of ducts in a quarter varied from 7 to 24 , mean $16.7 \pm 1.3$ in each quarter, and no difference in number of ducts was found between lactating and dry quarters. Major ducts, of which storing capacity exceeds ten percent of the whole milk storing capacity in a quarter, were mostly located toward the fore or rear directions. They occupied $75.56 \%$ and $72.14 \%$ of capacities of fore and rear quarters in lactating cows, and $77.32 \%$ and $66.02 \%$ in dry cows. For growing heifers, capacity of cistern and duct systems in fore quarters formed $44.02 \%$, $47.83 \%$, and $47.32 \%$ of those of whole udder, at the age of 10,20 , and 25 to 30 months, respectively. Duct system of udder developed uniformly in these heifers. The number of ducts in heifers at the age of 30 months had increased to similar number as in mature cows.

Jpn. J. Zootech. Sci., 56 (9): 736-743, 1985
\end{abstract}

The udder is made up of series of systems which includes the supportive structures, a duct system for storage and conveyance of milk and secretory units of epithelial cells. Each of these components directly or indirectly to the synthesis of milk. It is well known that the synthesis of milk is controlled in part by the pressure in the alveoli lumina due to the accumulation of milk ${ }^{1}$. It is also assumed that the pressure within the teat cistern reflects that within the lumina of the alveoli2).

From studies on the aqueous phase of milk and the electrochemical gradients between milk and extracellular fluid, LINzELL and coworkers ${ }^{3,4,5)}$ proposed that in the 
ducts, maintenance of milk composition is achieved by the simple expedient of impermeability to ions and lactose but not to water, and the secretory cells are permeable to ions but not to lactose once secreted. The storage of milk means that we are really dealing with two mechanisms that produces and then maintain the composition of milk in the alveoli and ducts. SHINDE ${ }^{6}$ ) demmonstrated that the removal of milk from the duct system increases the milk yield by promoting the rate of proliferation and activity of secretory cells during early lactation and reduces the rate of involution after the peak. It seems that the storing capacity, form and location of the duct systems have effect upon mammary function in cows. Little works have been done in this area. The experiment reported here have been attempted to develop a method of latex cast model of milk storing system and to clarify the structure and holding capacity of the milk storing system.

\section{Materials and Methods}

Udders of ten lactating, ten dry Holstein cows and three growing heifers were collected. Immediatly after slaughter the udders were excised. rinsed to remove the blood clots and trimmed of any excess connective and fat tissues. Milk in the udders were removed as much as possible by physical massaging of the udder. The udders were separated into halves through the medial ligaments, then the halves were weighted.

The injection medium used was latex (Neoprene 601-A, Kyoritsukasei Ldt) and diluted to 1:1 in volume with water. A glass bottle with an I. D. of approximately $10 \mathrm{~cm}$ and $30 \mathrm{~cm}$ in length was used to hold the latex. A piece of glass tubing which fit into the tubing on the teat cannula was inserted into a rubber stopper which was large enough to plug one end of the glass bottle. The latex was then poured into the open end of the bottle, taking care not to trap any air bubble, then allowed the latex to fill the glass tubing. The free end of the tubing connected to the teat cannula was filled with latex and connected to the bottle. Careful manipulation at this point prevented any air from entering the system. The latex was now allowed to flow into the udders from the bottle, which can be vertically clamped, above the udders. The latex had density slightly greater than water and filled the duct systems well beyond the point of branching, flowing under its own hydrostatic pressure. Optimum filling was ensured by a gradual rise in intramammary pressure to a maximum of about 150 $\mathrm{mm} \mathrm{Hg}$. When injection was completed, the tubing above the teat cannula was clamped and the bottle was removed off. After injection, the half of the udder was placed in a container filled with hydrochloric acid for vulcanization of latex and digestion of the tissue. When the corrosive solution was fresh, digestion was completed within 3 days and the cast was removed and rinsed in clean water. A short soaking in either diluted acid or base neutralized any remaining digestion fluid and a final wash completed the procedure. 
A preliminary experiment on the latex casts of various sizes revealed that the cast suffered a volume shrinkage of $25.33 \pm 0.04 \%$. Corrections of volume for latex models were made for the effect of shrinkage by adding this value.

\section{Results and Discussion}

Empty weight and volume of lactating cow's udder were $18.14 \pm 5.96 \mathrm{~kg}$ and $18.26 \pm$ 5.861 , and udder of dry cow were $14.36 \pm 6.11 \mathrm{~kg}$ and $14.45 \pm 5.891$. The difference between udder weight or volume of lactating and dry cows was not significant. The udder's weight of dry cows was lower than those reported by ANDERSon et al. ${ }^{7}$, although those of lactating cows were similar to them. The explanation for this discrepancy is that most of the udders in dry cows in this study were obtained during early stage of dry period. On the other hand, the avrage milk storing capacity of left half of udders for lactating cows was 4.71 \pm 0.921 and $2.85 \pm 0.691$ for dry cows (Table 1 ). There was significant difference in the milk storing capacity of the left of the udder between dry and lactating cows $(P<0.05)$. The results implied that in the bovine udder during early stage of dry period, the mammary lobules are reduced to a few branching ductules. Milk storing capacity of the fore quarter was $39.05 \%$ of the half-udder in lactating cows (Table 1). This agreed with a former investigation ${ }^{8}$, which showed that the fore quarters of udder were smaller than the rear quarters and on the average secreted $43.00 \%$ of daily milk yield. In dry cows, the capacity of fore quarters was $37.81 \%$ of the left half of the udder.

As can be seen in Fig. 1, 2, the cistern of the gland was a cavernous opening of variable size and comformation. Gland cisterns were classified according to their shape into five types (Fig. 2); divergent, ball, egg, columnar and part-divergent types. The percentage in the frequency distribution at each type was $45,12.5,10$,

Table 1. Volumes of milk storing system in left half of udder ${ }^{11}$

\begin{tabular}{ccc}
\hline Measurment & $\begin{array}{c}10 \text { Lactating } \\
\text { udders }\end{array}$ & \multicolumn{1}{c}{$\begin{array}{c}\text { 10 Dry } \\
\text { udders }\end{array}$} \\
\hline Vol. of fore quarter $(l)$ & $1.85 \pm 0.35$ & $1.08 \pm 0.32^{*}$ \\
rear quarter $(l)$ & $2.86 \pm 0.60$ & $1.77 \pm 0.43^{*}$ \\
half $(l)$ & $4.71 \pm 0.92$ & $2.85 \pm 0.69 *$ \\
Vol. of fore quarter as \% of half & $39.05 \pm 5.95$ & $37.81 \pm 7.73$
\end{tabular}

1) Mean \pm standard deviation. $* \mathrm{P}<0.05$. Significantly different from lactating udders.

Table 2. Frequency in appearance of the types of gland cistern in cow's udder

\begin{tabular}{lccccc}
\hline \multirow{2}{*}{ Udder } & \multicolumn{5}{c}{ Shape of gland cistern } \\
\cline { 2 - 6 } & Divergent & Ball & Egg & Columnar & Part-divergent \\
\hline Lactating & 7 & 2 & 3 & 4 & 4 \\
Dry & 11 & 3 & 1 & 2 & 3 \\
Total & 18 & 5 & 4 & 6 & 7 \\
Frequency proportion (\%) & 45 & 12.5 & 10 & 15 & 17.5 \\
\hline
\end{tabular}



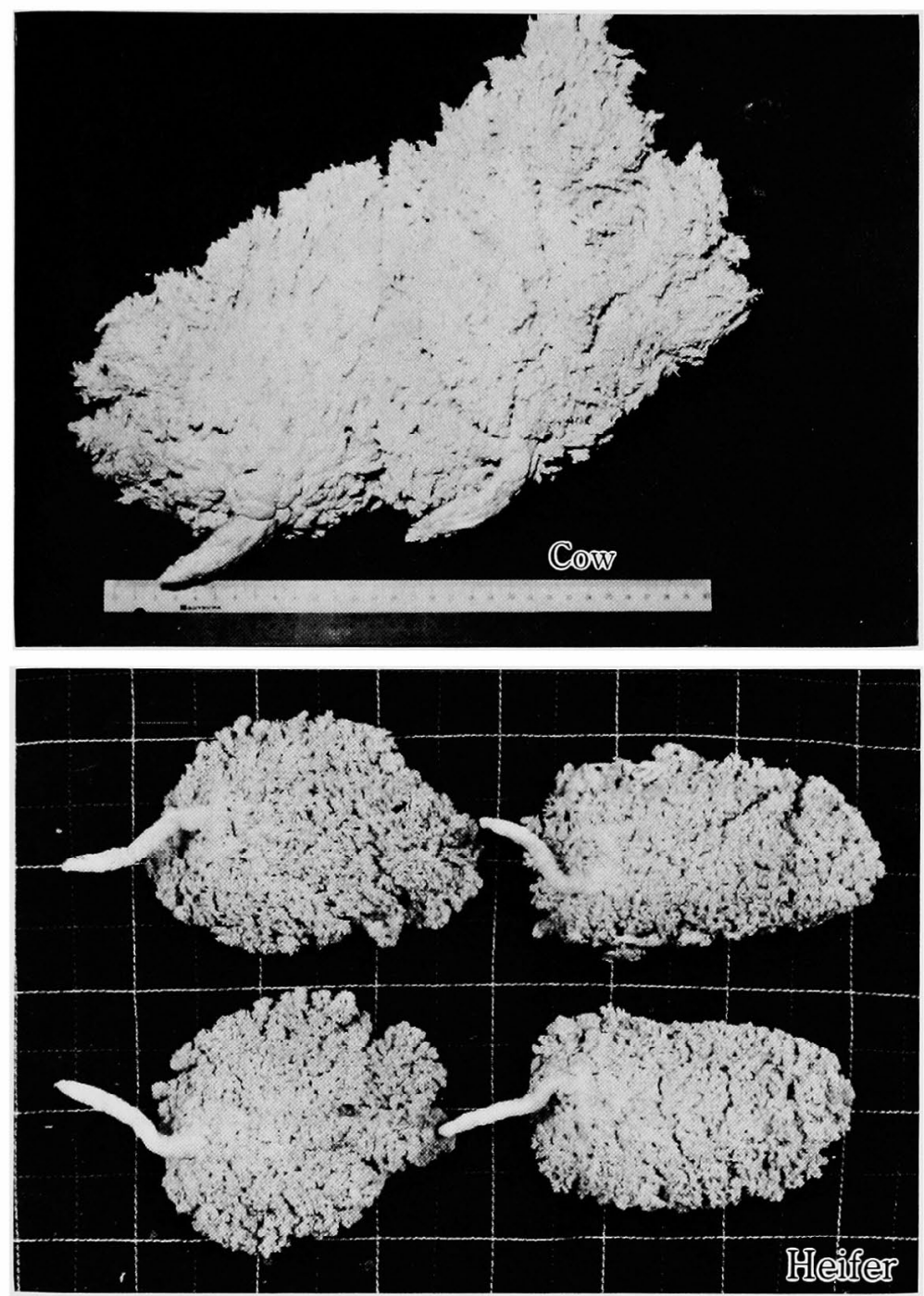

Fig. 1. Latex casts of milk storing system in lactating cow and growing heifer.

15 , and $17.5 \%$, respectively (Table 2 ). In the divergent type, central cistern was entirely lacking. The cistern was replaced by large ducts from which branches were extended in all directions. The branches were constricted at their point of connection with large ducts. The total volume of the teat and gland cisterns varied from $37.5 \mathrm{ml}$ to $174.1 \mathrm{ml}$ with the mean of $114.90 \pm 34.94 \mathrm{ml}$ in lactating quarters. This figure was smaller than that reported by TURNER ${ }^{9}$, in which the capacity of gland cistern was $100 \mathrm{ml}$ to $400 \mathrm{ml}$. The size of cistern varied greatly in different cows and in different quarters of the same udder. No correlation seemed to be present between the capacity of gland cistern and that of duct system; therefore, there is no relationship between the size of the cistern and the amount of milk secreted by the quarter.

The number of ducts varied from 7 to 24 , mean $16.7 \pm 1.3$ in each quarter, and 


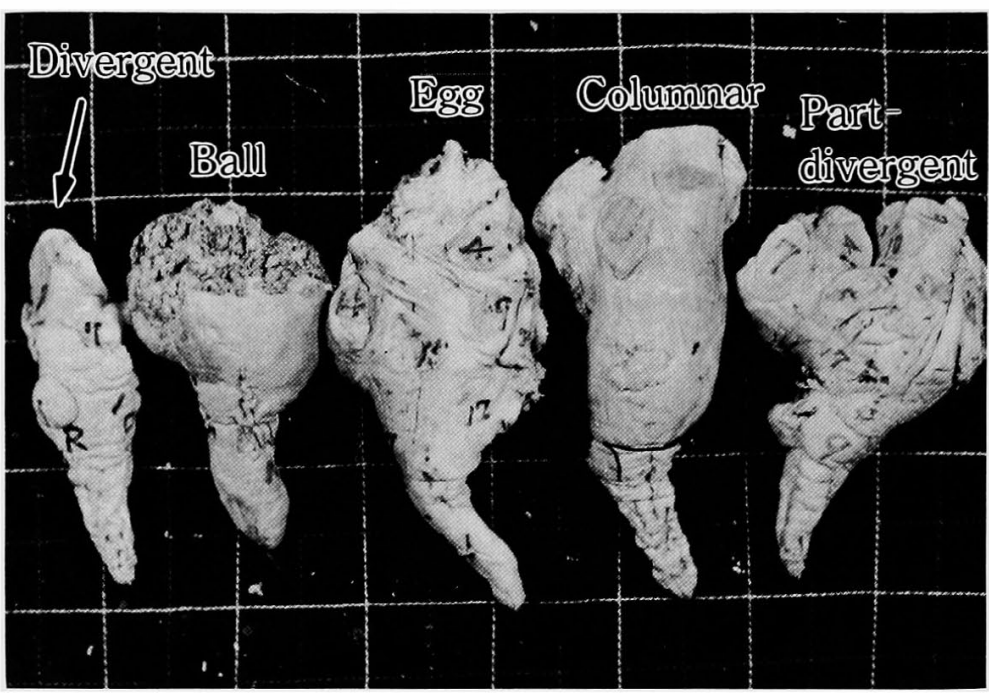

Fig. 2. Illustrations of several types of gland cistern, observed in quarters of udder in cows.

Table 3. Distribution and volume of duct system in the udder of cows ${ }^{1)}$

\begin{tabular}{|c|c|c|c|c|c|}
\hline \multirow[b]{2}{*}{ Udder } & \multirow{2}{*}{$\begin{array}{l}\text { Distribution } \\
\text { of duct }\end{array}$} & \multicolumn{2}{|c|}{ Fore quarter } & \multicolumn{2}{|c|}{ Rear quarter } \\
\hline & & $\begin{array}{l}\text { Volume of } \\
\text { duct }(\%)^{2)}\end{array}$ & $\begin{array}{c}\text { Number of } \\
\text { duct }\end{array}$ & $\begin{array}{l}\text { Volume of } \\
\text { duct }(\%)^{2)}\end{array}$ & $\begin{array}{l}\text { Number of } \\
\text { duct }\end{array}$ \\
\hline \multirow[t]{5}{*}{ Lactating } & Fore side & $25.12 \pm 11.97$ & $4.5 \pm 2.5$ & $21.33 \pm 18.92$ & 4. $4 \pm 2.5$ \\
\hline & Rear s. & $37.19 \pm 12.01$ & $5.0 \pm 1.5$ & $47.77 \pm 15.72$ & $3.6 \pm 1.4$ \\
\hline & Lateral s. & 10. $48 \pm 14.17$ & $3.2 \pm 1.9$ & $11.25 \pm 12.61$ & $4.3 \pm 1.6$ \\
\hline & Medial s. & $20.92 \pm 11.08$ & 3. $8 \pm 1.4$ & $15.53 \pm 10.93$ & $3.6 \pm 1.8$ \\
\hline & $\begin{array}{l}\text { Teat and } \\
\text { gland cistern }\end{array}$ & $6.29 \pm 1.80$ & & $4.13 \pm 1.37$ & \\
\hline \multirow[t]{5}{*}{ Dry } & Fore side & $29.61 \pm 19.65$ & 4. $4 \pm 2.2$ & $28.61 \pm 14.57$ & $5.3 \pm 2.4$ \\
\hline & Rear s. & $21.60 \pm 10.85$ & 3. $5 \pm 2.0$ & $42.44 \pm 19.73$ & $4.4 \pm 1.7$ \\
\hline & Lateral s. & $18.53 \pm 15.29$ & $3.1 \pm 2.1$ & $9.43 \pm 5.24$ & 4. $5 \pm 2.7$ \\
\hline & Medial s. & $19.48 \pm 21.82$ & $4.8 \pm 2.3$ & $11.19 \pm 12.32$ & $4.4 \pm 2.7$ \\
\hline & $\begin{array}{l}\text { Teat and } \\
\text { gland cistern }\end{array}$ & $10.78 \pm 5.26$ & & $8.32 \pm 5.54$ & \\
\hline
\end{tabular}

1) Mean \pm standard deviation. 2) Volume of duct, or cistern, expressed as a percentage the total volume of milk storing system.

no difference in number was found between lactating and dry quarters. Ducts in the lactating cows were grouped by location; located in the rear, fore, medial, and lateral side in a quarter, in the order of capacity of the ducts grouped. The capacity of ducts located in the front side in the fore quarter was similar to that in the rear side, while the capacity of the ducts in the rear side in the hind quarter was larger than that in the front side of the quarter (Table 3, Fig. 3). In case of the dry cows, ducts mainly located in the fore and rear sides in a quarter like as lactating cows. 
The Latex Cast of Caw's Udder

Table 4. Volume of cistern and duct system of the udder in growing heifer

\begin{tabular}{|c|c|c|c|}
\hline \multirow{2}{*}{ Measurement } & \multicolumn{3}{|c|}{ Cow number } \\
\hline & $\mathrm{H}-1$ & $\mathrm{H}-2$ & $\mathbf{H}-3$ \\
\hline Age, month & 10 & 20 & $25 \sim 30$ \\
\hline Weight of udder, $g$ & 1,110 & 1,240 & 6,220 \\
\hline Volume of udder, $\mathrm{m} l$ & 1,220 & 1,275 & 6,470 \\
\hline \multicolumn{4}{|l|}{ Volume of cistern and duct system } \\
\hline Fore half, $\mathrm{m} l$ & 108 & 133 & 854 \\
\hline Rear half, $\mathrm{m} l$ & 138 & 145 & 1,213 \\
\hline Udder, $\mathrm{m} l$ & 246 & 278 & 2,067 \\
\hline Fore half/Udder, $\%$ & 44.02 & 47.84 & 41.32 \\
\hline $\begin{array}{l}\text { Vol. of cistern and duct system/Vol. of udder, \% } \\
\text { Number of duct of quarter }\end{array}$ & 20.16 & 21.80 & 31.95 \\
\hline Fore quarter & 10 & 12 & 15 \\
\hline Rear quarter & 15 & 22 & 23 \\
\hline
\end{tabular}

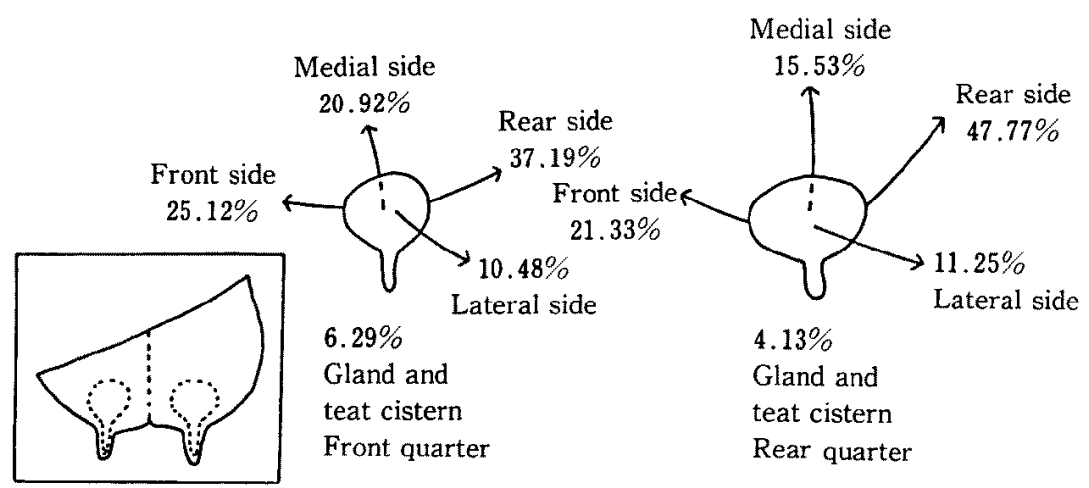

Fig. 3. Diagrams illustrating the location of major ducts, observed on quarters of udder in lactating cows.

Major ducts, of which millk holding capacity exceed ten percent of the whole capacity of a quarter, are mostly located in the fore and rear side of the quarter. They occupied $75.56 \%$ and $72.14 \%$ of the capacities of the fore and rear quarters. Involution of major ducts in the rear quarters may proceed faster than that of the fore quarters since the percentage of major ducts was lower in the rear quarters. There was also another difference in distribution of major ducts between lactating and dry udders. The capacity of major ducts in the medial side of rear quarters averaged $19.82 \%$ of whole milk storing system in lactating udders while there was no any distribution of ducts in the medial side of dry udder. This indicates that involution occures at first in the medial side in the rear quarter.

In growing heifers, the capacity of cistern and duct systems in the fore quarters formed $44.02 \%, 47.83 \%$, and $47.32 \%$ that of the whole udder, at the age of 10,20 , and 25 to 30 months, respectively (Table 4). These results agreed with those from lactating and dry cows and seemed to indicate that the difference in the capacity 
between the fore and rear quarters took place at an early age in the heifer. The duct system in the udder developed uniformly in these heifers. The heifers at the age of 30 months had a similar number of ducts in the udder as in mature cows.

Since the removal of a cast from the udder is a destructive proess, comparisons of different casting techniques using the udder are not possible. This problem has also hindered establishment of a standardized morphometric method; one can only strive to eliminate as many artifacts as possible. To our knowlege, the ideal casting material does not exist. Since there are some differences in physical properties between casting materials and milk, one must consider gravitational effects. The lower pressure injection of the casting material is required to prevent excessive distension of the duct systems. The technique used in the present study made it possible to obtain a good filling of milk storing system down to lobule level, when the viscosity of the material is appropriate. The volume of a cast can be easily computed from its mass and correction for shrinkage. The cast can also be used to estimate before hand the size and shape of milk storing system in cows and growing heifers.

\section{References}

1) Tucker, H. A., R. P. Reece and R. E. Mather., J. Dairy Sci., 44: 1725-1732. 1961.

2) Graf, G. C. and D. M. Lawson., J. Dairy Sci., 51: 1672-1675. 1968.

3) Linzell, J. L. and H. Peaker., J. Physiol., 216: 683-700. 1971.

4) Linzeli, J. L. and H. Peaker., J. physiol., 244: 771-782, 1975.

5) Fleet, I. R. and H. Peaker., J. Physiol., 279: 491-507. 1978.

6) Shinde, Y., in Physiology of Mammary Gland. (Yokoyama, A., H. Mizuno and H. NagaSawa, eds), 347-360. Japan Scientific Societies Press. Tokyo. 1978.

7) Anderson, R. R., M. H. LU, J. J. Trojanor and J. L. Clark., J. Dairy Sci., 57: 1350-1354. 1974.

8) Suzukr, S. and Y. Shinde, Machine Milking, 5: 15-21. 1963. (Japanese).

9) Turner, C. W., in The Mammary Gland. Vol. 1. 32-33. Lucas Brothers, Columbia. 1952. 


\section{乳牛の乳房における乳槽および乳管系の \\ ラテックス鋳型について \\ 新出陽三・桜井正和 \\ 帯広畜産大学, 帯広市 080}

乳牛の乳汁眝溜系の容積およびその構造を調べるため に，乳牛の乳房の乳槽および乳管系の鋳型を作製した。 型の作製には，泌乳牛 10 頭，乾乳牛 10 頭および末経 産牛 3 頭の乳房を用いた。

1）経産牛および未経産牛の乳房の乳汁眝溜系の容積 や形態を調べる目的にラテックスの鋳型は有効な手段で あることを示した。

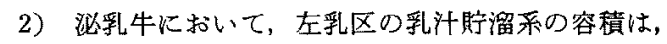
$4.71 \pm 0.92 l$ (平均値士準偏差) て, 前乳区の容量は全 体の 39.05\%であった。一方，乾乳牛の左乳区に和いて は，乳斗睆溜系の容積が $2.85 \pm 0.96 l$ で，前乳区の容積 は，全体の $37.81 \%$ となった．乳汁貯溜系の容積には， 泌乳牛と彰乳牛の間に有意な差が認められた $(\mathrm{P}<0.05)$.

3) 乳槽の形態は分岐型: $45 \%$, 球型: $12.5 \%$ 玉子型:
10\%, 円柱型：15\%，部分分岐型：17.5\% に分類された. 4) 1 乳区の乳管の数は，7〜24 本で平均 $16.7 \pm 1.3$ 本であった，乳汁貯溜系の全容積の $10 \%$ 以上の容積を bつ乳管を大乳管とすれば，泌乳牛の大乳管は乳汗眝溜 系の全容積に対して前乳区で 75.56\%, 後乳区では 72.14 $\% の$ 容積を占めた。乾乳牛では前乳区で77.32\%後乳区 では 66.02\%を占めた。

5）未経産牛の前乳区の乳槽・乳管系の容積は10 か 月 路，20 か月龄，25〜30 か月踰でそれぞれ 全体の44.02 \%，47.83\%，47.32\%であった. 末経産牛の乳管の発達 は，全体的に均一で, 乳管の数は30か月龄で成牛とほほ 同じであった。

日蓄会報，56(9)：736-743，1985 